\title{
Stakeholders' Perspectives Of Accounting Faculty Time Allocations
}

\author{
Kimberly E. Frank (Email: kfrank@ccmail.nevada.edu), University of Nevada Las Vegas \\ D. Jordan Lowe (Email: dlowe@ccmail.nevada.edu), University of Nevada Las Vegas \\ Georgia Smedley (Email: smedley@ccmail.nevada.edu), University of Nevada Las Vegas
}

\begin{abstract}
This study provides evidence on how various stakeholder groups perceive faculty time is and should be allocated across teaching, research and service. To ascertain the priorities of various stakeholders, a questionnaire was administered to accounting professionals, accounting students, and taxpayers. Assistant professors were also surveyed to establish a benchmark for comparisons. Overall, the findings indicate a disparity between the perceptions of accounting professors and their stakeholders regarding time allocations. Suggestions on ways to mitigate these differences are offered.
\end{abstract}

\section{Introduction}

he question of how accounting faculty should be devoting their limited time has been debated for years. Over the past decade, various stakeholders (e.g., accounting professionals, taxpayers, and students) have expressed differing views as to the priorities of accounting faculty. Stakeholders' assessments have resulted in conflicting pressure for faculty regarding how to allocate time between research, teaching and service activities.

The importance of stakeholder beliefs regarding how accounting academics should use their time is driven in large part by a need for resources and support. Disenchantment with accounting academics could adversely affect future funding levels as many public institutions are generally at the mercy of state budgets and legislative allotments. Taxpayers have influence over the level of educational funding through their influence over university regents and the voting process. The accounting profession has historically provided support to accounting departments and their faculty through (1) direct financial contributions, (2) assistance with fundraising, (3) serving on advisory boards, (4) providing faculty and student internships, and (5) making classroom presentations (AAPG Practice Involvement Committee, 1995). In recent years this support has been inconsistent and overall has diminished (Read et al., 1998). In fact, Cook (1989) calls for practitioners to exert their influence over academia by restricting financial contributions or directing them towards specific endeavors. Accounting professionals can also reward or penalize schools they believe are or are not successful by targeting recruiting efforts toward schools that are deemed successful (Beaver, 1992). Furthermore, students can vote "with their feet" by selecting academic programs or universities that meet their individual needs, resulting in tuition dollars being allocated to select institutions.

The dilemma of faculty time allocation is heightened as many colleges and universities are faced with budget shortages. Higher education is increasingly being asked to do more with the same or reduced resources (Read et al., 1998). Further, public accounting firms are providing fewer financial resources to (academic) accounting departments and what is being provided often has "strings attached" (AAPG Practice Involvement Committee, 1995). For example, dollars are often earmarked for specific activities such as student scholarships.

Readers with comments or questions are encouraged to contact the authors via e-mail.

While the financial situation will vary across institutions, it is clear that for accounting departments to survive and be successful they must recognize the concerns of various stakeholders when determining the best use of faculty 
time.

\section{Literature Review}

Prior research indicates diverse viewpoints regarding how accounting faculty should be allocating their efforts and whether the needs and desires of stakeholders are being met. During the last decade several stakeholders have indicated that teaching should be given the highest priority in higher education (AAPG Practice Involvement Committee, 1995; Elliott, 1991). Other related research (e.g., Strait and Bull, 1992; WSJ, 1990) indicates that the general public believes that the primary mission of higher education is to educate students rather than performing research. This perception may partially be due to the public's knowledge of the benefits of teaching and a corresponding lack of knowledge of research and its potential value to students and to the profession. Academia should consider that stakeholders cannot be expected to have an appreciation for research when they haven't been exposed to the findings or methods in their education.

Conversely, other studies suggest that research is quite beneficial and may have significant importance to academia and the accounting profession. Carver and King (1986) report that practitioners view accounting research as useful as a means of improving the profession. They also note that only one third of the respondents believed that too much emphasis is placed on research by higher education. However, there is some concern, given that seventyfive percent of the respondents thought the research focused on abstract problems rather than practical issues of immediate importance. On a related note, Wright (1994) found that students perceive a strong need for accounting research and believe a significant amount is being done. However, this group of students also admits to largely misunderstanding academic research and its underlying purpose.

A key premise of this debate has been the assumption that time spent on research takes away from effective teaching and thus there is a distinct tradeoff between these objectives (Beaver, 1992). However, Reinstein and Lander (1993) found that practicing accountants, students and academics generally do not believe that research distracts professors from their classroom performance and agree that the research done by professors benefits the students' preparation for the work environment. Moreover, Bell et al. (1993) and Lindsay and Campbell (1995) found a positive relationship between research productivity and teaching effectiveness.

While stakeholders' beliefs are important, of equal importance are accounting faculty and administration views about the use of professors' time. Certainly professors must be mindful of how they will be evaluated and rewarded if they want to obtain tenure and promotions. Anderson and Clyde (1997) examined how assistant professors and chairpersons in accounting perceive the importance of research, teaching and service in promotion and tenure decisions. Their results revealed that assistant professors weighted research the highest (65 percent) followed by teaching ( 26 percent) and service (9 percent). Chairpersons provided similar assessments as follows: research (53 percent), teaching (37 percent) and service (10 percent). Bohrer and Dolphin (1985) and Schultz et al. (1989) found that college deans place an inordinate amount of emphasis on research productivity in the tenure and promotion decisions. More recently, Street, et al. (1993) reported that deans and accounting department chairmen value research differently according to their Carnegie classification with a greater emphasis at Research I schools compared to Comprehensive schools. However, even at the Comprehensive schools the importance of research (on a $0-100$ scale) is weighted at approximately 40 percent of the tenure and promotion decisions. This is consistent with the findings that publication productivity has generally increased at non-doctoral institutions (Read et al., 1998) and that other traditionally "teaching oriented" schools now require publications in refereed journals (Hermanson et al., 1995). The fact remains that over the last half-century there has been an increased emphasis on research as assistant professors struggle to "publish or perish".

Overall the results of these studies make it difficult to discern the particular priorities stakeholders would have faculty pursue. Research to date has not examined the differences in perceptions across various stakeholders regarding how faculty should be allocating their time across teaching, research and service activities. In general, most studies examine only one group (usually accounting professionals or professors) or one dimension of a professor's activities. This study attempts to provide some descriptive evidence on how various stakeholders and accounting faculty perceive time allocations. First, we examine how taxpayers, students and accounting 
professionals perceive assistant professors are currently allocating their time. Second, and more important, we investigate these stakeholders' assessments regarding how assistant professors should be allocating their time. The stakeholders' beliefs are also compared with the beliefs of assistant professors to determine whether these groups are moving in similar or different directions. Differences between beliefs and expectations of time allocations provide evidence of whether discord exists across stakeholders. Mitigating these differences either through shifting priorities and/or educating stakeholders on the implications and outcomes associated with different activities will be important if accounting departments want to attract and retain resources. The comprehensive approach taken here recognizes that time is limited and tradeoffs are necessary. These current findings provide a starting point for reconciling differences between the various stakeholders and academia and for tracking changes in perceptions regarding accounting faculty over time.

\section{Method}

\section{Participants}

In order to determine the values stakeholders place on teaching, research, and service, a questionnaire was prepared and administered to three different stakeholder groups — taxpayers, students and accounting professionals. We also surveyed current assistant professors of accounting to ascertain their perceptions

Prospective jurors (hereafter jurors) were chosen as surrogates for taxpayers. While the two populations are not identical, jurors are drawn from the pool of registered voters. It is the voting power of these individuals that influences the resources allocated to education, making them a reasonable proxy. Juror responses were collected over five separate days at the County Courthouse in a large southwestern city; 100 surveys were completed. Jurors (who expressed willingness to participate) completed the survey in quiet conference rooms while waiting for selection and were subsequently compensated $\$ 5.00$. Jurors' ages ranged from 18 to 78 , with a mean of 41 . Sixtytwo percent of the jurors were female and 63 percent were married. In terms of educational background, 54 percent were college graduates and all but one juror was a high school graduate.

Senior-level accounting students from three different large (enrollment greater than 20,000), public universities participated in the study. One school offers a doctoral degree in accounting and the other two offer masters in accounting degrees. Ninety-nine students completed the survey as part of an in-class activity. The average age of the students was $22 ; 55$ percent were female.

A random sample of CPAs provided by the American Institute of Certified Public Accountants (AICPA) was used to collect data from accounting professionals. Two hundred-seventy questionnaires were mailed and 102 usable responses were received, resulting in a 37 percent response rate ${ }^{1}$. The sample included a variety of CPA ranks with an average of 13 years experience being reported. The accounting professionals had a mean age of 39; 76 percent were male.

Assistant professors were also surveyed as a baseline for comparisons to the respective stakeholders. We chose this academic rank as assistant professors are often perceived as having the most conflict and pressure in maintaining their roles across the respective academic areas. We sampled assistant professors from public universities representing a cross-section of strong teaching and research institutions. We used several criteria in which to narrow our sample of institutions. ${ }^{3}$ The criteria were patterned after those used in Schoeder and Saftner (1989). One hundred ninety-three questionnaires were mailed and ninety-nine responses were received resulting in a 52 percent response rate. The assistant professors represented a wide variety of teaching/research specializations and geographical locations. Seventy-one percent of the respondent schools had MBA programs, 59 percent had Masters of Accountancy programs, and 71 percent had Ph.D. programs. ${ }^{2}$ All the schools had business school accreditation by the AACSB with an additional 60 percent having separate accounting program accreditation. The professors reported an average age of 36; 69 percent were male. In addition, 58 percent indicated that they were currently a CPA.

Survey 
In the first part of the survey, participants were asked to allocate the time the average assistant professor (in accounting) would actually spend (1) teaching; (2) conducting research; and (3) providing service. We informed participants as to the meaning of the rank of assistant professor to ensure that all participants were equally aware of this term. To obtain a consistent response, respondents were instructed to divide 100 percent of available time among the three areas. The allocation of an abstract quantity (i.e., 100 percent) provides insight into the priorities associated with each activity. It also serves as a reminder that time is limited and tradeoffs often have to be made. In addition, all respondents were asked to allocate the 100 percent of available time an average professor should spend in each of the three areas.

To obtain a better understanding of the stakeholders' beliefs on teaching and research, several additional questions were asked. The second part of the survey asked respondents to indicate the actual number of hours they believed professors do and should spend in the classroom to get a better appreciation for the time they believe should be dedicated to teaching. Participants were also asked to respond to two statements about research. The first asked participants to indicate their agreement with the statement that "Accounting research should be conducted in an effort to solve current problems of the accounting profession (CPA firms and industry) using a 10-point scale with 1 indicating 'strongly disagree' and 10 'strongly agree'. The second question asked participants to indicate their belief regarding the contribution of accounting research to society in comparison to the sciences using a 10point scale with 1 indicating 'very little contribution' and 10 indicating 'large contribution'.

The final section of the survey addressed assistant professor training. Respondents were first asked to determine the relative percentage of training an average professor receives in the three responsibility areas while in graduate school (allocating 100\% of available time between teaching, research, and service). The second question addressed the participants' beliefs about the relevance of practical experience to the teaching effectiveness of professors. Participants responded to the statement "To what extent should new accounting professors at major, public universities have extensive accounting work experience, in order to be effective as professors?" using a tenpoint scale with 1 indicating 'not at all' and 10 indicating 'to a great extent'.

\section{Results}

For the questions that involved the allocation of time over (1) teaching, (2) research, and (3) service we initially utilized multivariate analysis of variance (MANOVA) to analyze whether responses taken together are significant across the different groups. We performed this analysis given that these questions were related and significantly correlated with each other. ${ }^{4}$ For the remaining questions we employed univariate analysis of variance (ANOVA) to test for differences among the group responses. The MANOVA and ANOVA results revealed that for each analysis, the mean differences across the groups was significant at $\mathrm{p}<0.0001$. However, our primary emphasis was upon performing individual contrasts to compare the responses of the three stakeholder groups to the benchmark responses of the assistant professors.

\section{Time Allocation}

Mean responses to the questions of how accounting professors are believed to spend their time and how they should spend their time are reported in Table 1. In general, stakeholders' perceptions of time actually spent on teaching, research and service differ from those reported by the assistant professors (panel A). Accounting professionals believe that professors spend significantly $(\mathrm{p}<0.01)$ more time on teaching $(50$ percent) than professors state that they do (44 percent). Both taxpayers and accounting professionals perceive that significantly $(\mathrm{p}<0.01)$ less time is spent on research (33 and 34 percent) than professors report (44 percent) and all three groups of stakeholders indicate significantly higher percentages of time spent in service than reported by professors. These differences shed light on how little taxpayers and practicing accountants know about how faculty actually spends their time. It is not surprising however that student' responses are similar to the actual time reported by professors given their close interactions with faculty. 
Table 1

Time Allocation Perceptions ${ }^{\mathrm{a}}$

Panel A: Perceptions of ACTUAL time allocations

\begin{tabular}{lcccc} 
& Taxpayers & Students & $\begin{array}{c}\text { Accounting } \\
\text { Professionals }\end{array}$ & $\begin{array}{l}\text { Assistant } \\
\text { Professors }\end{array}$ \\
\hline Teaching & $47 \%$ & $40 \%$ & $50 \%$ & $44 \%$ \\
Research & 34 & 44 & 33 & 44 \\
Service & 19 & 16 & 17 & 12 \\
& & & & \\
\hline
\end{tabular}

Panel B: Perceptions of OPTIMAL time allocations

$\begin{array}{llllc}\text { Teaching } & 54 \% & 60 \% & 64 \% & 40 \% \\ \text { Research } & 26 & 24 & 21 & 51 \\ \text { Service } & 20 & 16 & 15 & 9\end{array}$

Panel C: Perceptions of HOURS spent in the classroom

$\begin{array}{lrrrr}\text { Actual } & 20.2 & 8.5 & 15.4 & 6.7 \\ \text { Optimal } & 23.9 & 11.0 & 21.3 & 7.5\end{array}$

${ }^{\mathrm{a}}$ Mean differences across groups are significant at $\mathrm{p}<0.0001$.

In Panel B of Table 1, stakeholders' perceptions of the optimal allocation of time compared to assistant professors indicates significant differences $(p<0.01)$ across each category. Consistent with the AECC's recommendation that teaching be given more priority over research (AECC, 1990), all three groups of stakeholders thought significantly more time should be devoted to teaching and less time to research than did the assistant professors. The result is similar for service as well. What is interesting to note is how the time allocations shift between their beliefs about how time is actually spent versus how it should be spent. Tests of the differences in mean values within groups for each dimension indicate that stakeholders added time to teaching at the expense of research (all differences significant at $\mathrm{p}<0.03$ ), leaving service consistent between the actual and optimal time allocations. This was particularly so with students. Students assessed that assistant professors spent about 40 percent of their time teaching, and yet preferred that their professors devote approximately 60 percent of their time to teaching. On the other hand, assistant professors added time to research (51 vs. 44 percent, $\mathrm{p}=0.14$ ) while holding teaching fairly constant $(\mathrm{p}=0.10)$ but taking time away from service $(\mathrm{p}=0.02)$. This is not surprising given the evidence that suggests their tenure and promotion decisions are largely based on research productivity.

The last panel of Table 1 shows stakeholders' perceptions of the actual (contact) hours spent in the classroom and the optimal hours that should be spent in the classroom. The significant differences in hours, reported in Panel C, suggest the perceptions of stakeholders were even further from the responses of assistant professors than the time allocation results suggest. The amount of time reported by assistant professors is consistent with typical teaching loads (6.7 hours) at major, public universities. However, by not forcing consideration of tradeoffs between research, service or even outside preparation for class as done in the first part of the analysis, the stakeholders believed that considerably more time is actually spent in the classroom than is reported by the assistant 
professors. Similar results are found for the optimal amount of time that should be spent in the classroom.

The disparity in hours that assistant professors actually (and should) spend in class was greatest for taxpayers. Taxpayers perceived that assistant professors spend about 20.2 hours a week in class and that they should spend 23.9 hours $(\mathrm{p}=0.02)$. This misconception of classroom hours may be due to the lack of experience that the general public has with typical college professor workloads. We examined taxpayers' responses more closely by dividing the sample based on whether respondents were college graduates or not. We found that college graduates' responses were marginally significantly lower $(\mathrm{p}=0.08)$ than those not graduating from college for the actual time assistant professors spend in class and significantly lower $(\mathrm{p}=0.01)$ for how many hours they should be spending in

class. While this may be expected, it does illustrate that the general public is not familiar with the activities of college professors.

What was somewhat surprising was the accounting professionals' assessments for actual and optimal classroom hours $(15.4$ and 21.3 hours; $\mathrm{p}<0.01)$. Given that the accounting professionals in our sample had all attended college, they should be familiar with faculty teaching loads. Subsequent analysis did reveal, however, that the longer it had been since the professionals were in college (as measured by working experience, age, and/or rank in firm), the more time they perceived that assistant professors are and should be spent in the classroom. The students' views were more closely aligned to those of the assistant professor, and are a reflection of a closer interaction between the two groups. However, the difference between the number of hours students believe professor actually spend in class compared to the number they should is significantly different $(\mathrm{p}<0.01)$.

\section{Accounting Research Perceptions}

To follow-up on stakeholder beliefs about the amount of time that is and should be spent on research, two additional questions were asked about the type and contribution of accounting research. The results indicate that the stakeholders are significantly $(\mathrm{p}<0.0001)$ more likely than assistant professors to believe the focus of research should be directed towards current problems of the accounting profession (see Table 2). This is consistent with the findings of Carver and King (1986). However, it is interesting to note that stakeholders also perceive that accounting research is making a larger contribution to society than is indicated by assistant professors. Stakeholders responded near the midpoint of the (1-10) scale on the contribution to society question, whereas the assistant professors expressed a very low mean of 2.96 on this item. These results are somewhat disconcerting given the aforementioned responses for optimal time allocations. Ironically, assistant professors believed that more time should be spent on research, even though the contributions are minimal, while stakeholders believed the opposite.

Table 2

Perceptions of Accounting Research ${ }^{\mathrm{a}}$

\section{Accounting research should be conducted to solve current problems of the accounting profession (CPA firms and industry).}

10 point scale: $1=$ strongly disagree, $10=$ strongly agree

\begin{tabular}{lccc} 
Taxpayers & Students & $\begin{array}{c}\text { Accounting } \\
\text { Professionals }\end{array}$ & $\begin{array}{c}\text { Assistant } \\
\text { Professors }\end{array}$ \\
\hline
\end{tabular}

7.22

7.20

7.21

6.42 


\section{In comparison to the sciences (chemistry, biology, physics, engineering, medicine) how would you evaluate the contributions of accounting research to society?}

10 point scale: $1=$ very little contribution, $10=$ large contribution

\begin{tabular}{llll} 
Taxpayers & Students & $\begin{array}{l}\text { Accounting } \\
\text { Professionals }\end{array}$ & $\begin{array}{l}\text { Assistant } \\
\text { Professors }\end{array}$ \\
\hline
\end{tabular}

$\begin{array}{llll}5.96 & 5.57 & 5.10 & 2.96\end{array}$

${ }^{\mathrm{a}}$ Mean differences across groups are significant at $\mathrm{p}<0.0001$.

Training of Accounting Professors

The last portion of the analysis examines the training accounting professors receive. To some extent the types of training professors receive is likely to affect the emphasis they place on different aspects of their job. There are two types of training assistant professors could obtain. First, is the training they may receive as an accounting professional prior to entering a graduate program. Professors may have experience working as an accountant that gives them insights into the issues of the profession, although few programs require incoming students to have accounting work experience (Meyer and Titard, 2000). Second, is the training received during graduate school. Typically, Ph.D. students receive little formal training in teaching and perform little if any service. The vast majority of time in graduate school is generally spent on research (Manakyan and Tanner, 1994; Strait and Bull, 1992).

The results presented in Table 3 indicate that each of the stakeholders are significantly $(\mathrm{p}<0.01)$ more likely than assistant professors to consider accounting work experience as being important in the training of new accounting professors. This speaks to the issue of directing research towards current problems of the profession. It is likely to be more difficult to understand the issues facing the accounting profession if you have no experience in that area. In addition, stakeholders perceived that graduate school training is far more diverse than that reported by assistant professors. Stakeholders all believed that the greatest percentage of time in a graduate program should be directed toward preparing graduate students to be effective teachers. This is compared to the actual benchmark indicated by assistant professors who stated that only seven percent of their graduate program was directed toward teaching activities. These findings are consistent with the time allocations stakeholders believe should be made by faculty. They also illustrate that stakeholders lack a fundamental understanding of the purpose and operation of Ph.D. programs in accounting.

Table 3

Perceptions of Professor Training ${ }^{\text {a }}$

To what extent should new accounting professors have extensive accounting work experience, in order to be effective professors?

10 point scale: $0=$ Not at all to $10=$ To a great extent

\begin{tabular}{llll} 
Taxpayers & Students & $\begin{array}{l}\text { Accounting } \\
\text { Professionals }\end{array}$ & $\begin{array}{l}\text { Assistant } \\
\text { Professors }\end{array}$ \\
\hline
\end{tabular}


7.22

7.20
7.21

5.60

Percentage of time spent on professor training in graduate school

\begin{tabular}{lcccc} 
& Taxpayers & Students & $\begin{array}{c}\text { Accounting } \\
\text { Professionals }\end{array}$ & $\begin{array}{c}\text { Assistant } \\
\text { Professors }\end{array}$ \\
\cline { 2 - 6 } Teaching & $46 \%$ & $55 \%$ & $60 \%$ & $7 \%$ \\
Research & 32 & 32 & 28 & 93 \\
Service & 22 & 13 & 12 & 0 \\
\hline
\end{tabular}

${ }^{\mathrm{a}}$ Mean differences across groups are significant at $\mathrm{p}<0.0001$.

\section{Conclusion}

In general these findings reveal a disparity between the perceptions of accounting professors and their stakeholders regarding the allocation of time between teaching, research and service activities. Stakeholders believe more time should be spent on teaching than research and that the research performed should focus more on the practical, current problems of the profession. Assistant professors believe more time should be shifted towards research and less time spent on teaching and service.

One concern indicated by these results is the lack of awareness stakeholders have about the workings of accounting academia. Until stakeholders are educated about the operations of academia, their level of empathy and willingness to devote resources to the system may diminish. There are certainly issues that arise from the responses of accounting professors as well. After more than a decade of calls for increased emphasis on teaching and practical research, assistant professors believe the academic profession should be moving further away from this path. These responses are likely a reflection of the incentive system and training of assistant professors. Equally disturbing is their belief that research should be given a higher priority in spite of their perception that the research makes little contribution to society.

In conclusion, our study suggests that academia and their stakeholders need to converge on the priorities of accounting faculty. Academia should consider bearing the major responsibility for promoting this change. First, academic institutions need to create an environment that promotes greater accountability for the resources used and contributions of faculty. Second, we need to educate our stakeholders as to the training involved in Ph.D. programs in accounting. A step in this direction is a recent article by Meyer and Titard (2000) that describes in detail the requirements, expectations, and operations of Ph.D. programs in accounting. Third, accounting faculty and their respective institutions need to do a much better job of promoting the benefits and contributions of accounting research to their stakeholders. Faculty should demonstrate the relevance and transferability of research to the classroom and/or profession. Unless this is done, stakeholders may be unable to fully appreciate and value accounting research.

\section{Suggestions For Future Research}

This study contributes to our understanding on how various stakeholder groups perceive faculty time $i$ and should be allocated across teaching, research and service. This research suggests that the disparity of perceptions across these groups may at least in part be due to stakeholders' lack of understanding of the role and responsibilities of academic accountants. As such, research in this area certainly seems warranted. Future research should consider extending our study to an empirical research setting. That is, our survey results imply that the gap in perceptions across stakeholders could be lessened through education efforts. Research could directly test this by manipulating level of education across stakeholders in a between-subjects design. Education could be manipulated by having certain stakeholders given rather detailed information regarding the training, operating environment and research efforts of academic accountants. Results from such a study could provide some initial evidence as to whether 
stakeholders' divergence on perceptions relate to a lack of awareness or to a certain predisposition to academic efforts.

Future research should also be extended to professors. Additional research could be directed toward how the academic reward structure (e.g., tenure and promotion) influences accounting professors' perceptions regarding the teaching, research, and service mix. While we used assistant professors in this study, other research could utilize associate and full professors to better understand the underlying motivation for professors' perceptions.

Acknowledgements: The authors wish to acknowledge the helpful comments and suggestions by Elizabeth Almer, Tim Fogarty, and Marshall Geiger. The survey instrument is available from the authors upon request.

\section{Endnotes}

1. Collecting a specific number of survey instruments was possible with both the jurors and students due to the fact that surveys were administered until 100 were complete. To keep the sample sizes consistent we followed-up our initial mailings to AICPA member and assistant professors with additional mailings.

2. All schools selected had to have their business schools accredited by the AACSB at the undergraduate and, if applicable, the graduate levels. In addition, all schools listed on the Public Accounting Report's Top 20 Undergraduate and Graduate Programs were included. Other criteria used to select sample schools were the presence of a Macc program, MBA program, or Ph.D. program.

3. The percentages do not total $100 \%$ due to many schools having more than one program.

4. Multivariate techniques such as MANOVA require that the dependent measures are correlated in order to References have requisite statistical power (Johnson and Wichern, 1988).

1. AAPG Practice Involvement Committee, "Accounting faculty/practitioners partnership to address mutual education concerns," Issues in Accounting Education, Vol. 10, No. 1, pp. 197-206, 1995.

2. Accounting Education Change Commission, "AECC urges priority for teaching in higher education," Issues in Accounting Education, Vol. 5, No. 2, pp. 330-331, 1990.

3. Anderson, S. E. and N. J. Clyde, "The communication of tenure criteria: A comparison of administrator and faculty perceptions," Accounting Educator's Journal, Vol. 9, No.1, pp. 34-49, 1997.

4. Beaver, W. H., "Challenges in Accounting Education," Issues in Accounting Education, Vol. 7, No. 2, pp. 135-143, 1992.

5. Bell, T. B, T. J. Frecka and I. Soloman, "The relation between research productivity and teaching effectiveness: Empirical evidence for accounting educators," Accounting Horizons, Vol. 7,No. 4, pp. 33-49, 1993.

6. Bohrer, P. and R. Dolphin Jr., "Expectations and support for scholarly activity in schools of business," Journal of Education for Business, Vol. 61, No. 3, pp. 101-105, 1985.

7. Carver, M. R. and T. E. King, "Attitudes of accounting practitioners towards accounting faculty and accounting education," Journal of Accounting Education, Vol. 4, No. 1, pp. 31-43, 1986.

8. Cook, J. W.,"Practical actions for practical education," The CPA Journal, March, pp. 6-7, 1989.

9. Elliott, R. K., "Accounting education and research at the crossroad," Issues in Accounting Education, Vol. 6, No. 1, pp. 1-8, 1991.

10. Hermanson, D. R., H. M. Hermanson, D. M. Ivancevich and S. H. Ivancevich, "Perceived expectations and resources associated with new accounting faculty positions," Accounting Perspectives, Spring, pp. 53-73, 1995.

11. Johnson, R. and D. Wichern, Applied Multivariate Statistical Analysis $2^{\text {nd }}$ edition, Prentice Hall, New York, New York, 1988.

12. Lindsay, D. H. and A. Campbell, "The association of faculty research in accounting with a measurable teaching outcome: Evidence from the western region," Accounting Educators' Journal, Vol. 7, No. 2, pp. 69-90, 1995.

13. Manakyan, H. and J. R. Tanner, "Research productivity and teaching effectiveness: Accounting faculty perspective," Accounting Educators' Journal, Vol. 6, No. 2, pp. 1-21, 1994. 
14. Meyer, M. J. and P. L. Titard, “Those who can teach,” Journal of Accountancy, July, pp. 49-58, 2000.

15. Read, W. J., D. V. Rama and K. Raghunandan, "Are publishing requirements for accounting faculty promotions still increasing?," Issues in Accounting Education, Vol. 13, No. 2, pp. 327-339, 1998.

16. Reinstein, A. and G. H. Lander, "Scholarly Research and Teaching: Is there a disproportionate mix?," Journal of Education for Business, September/October, pp. 49-55, 1993.

17. Schroeder, N. W. and D. V. Saftner, "Accounting faculty promotion at quality institutions," Issues in Accounting Education, Vol. 4, No. 2, pp. 252-264, 1989.

18. Schultz, J. J., J. A. Meade and I. Khurana,"The changing role of teaching, research, and service in the promotion and tenure decisions of accounting faculty," Issues in Accounting Education, Vol. 4, No. 1, pp. 109-119, 1989.

19. Strait, A. M. and I. Bull, "Do academic traditions undermine teaching?," Journal of Accountancy, September, pp. 69-73, 1992.

20. Street, D. L., C. P. Baril and R. L. Benke Jr., "Research, teaching, and service in promotion and tenure decisions of accounting faculty," Journal of Accounting Education, Vol. 11, pp. 43-60, 1993.

21. Wright, A., "Research in accounting: student perspectives," Journal of Accounting Education, Vol. 12, No. 2, pp. 161-174, 1994.

22. WSJ Staff, “College Prices,” Wall Street Journal, March 12, p. A8, 2000. 